\title{
CORRELATION MODELS IN THE STUDIES OF STRUCTURE AND PROPERTIES OF AMIDES
}

\author{
A.S.Tulegenov ${ }^{1}$, G.V.Abramova ${ }^{1}$, Kh.Avchukir ${ }^{1}$, M.K.Nauryzbayev ${ }^{2}$, K.I.Imanbekov ${ }^{3}$ \\ ${ }^{1}$ al-Farabi Kazakh National University \\ ${ }^{2}$ Center of physical-chemical methods of analysis \\ ${ }^{3}$ named after Bekturov Institute of Chemical Sciences, Almaty
}

\begin{abstract}
The structures of the row of amides of saturated hydrocarbons were investigated. The amides of $C_{1}-C_{5}$ row were investigated. The equilibrium geometries of molecules were identified. The total electronic energies were computed at SCF, MP2 and PM3 levels of theory. The enthalpies of formation were computed at PM3 level of theory. The possibility of existence of several types of correlations was explored. The set of molecular properties was computed including: ionization potentials, partial charges on nitrogen atoms, protonation energies. Several correlations were identified including: linear relationship between experimental enthalpies and number of atoms, experimental enthalpies and SCF total electronic energies, MP2 and SCF total electronic energies, logarithm of ionization potential and the protonation energies for the series of amides.
\end{abstract}

\section{Introduction}

Amides are one of the most abundant compounds in nature. Their properties make them distinct in the row of organic molecules. Thus, amides may be considered as the prototypes of bioorganic molecules, the $\mathrm{CO}-\mathrm{NH}$ bond is the basic structural unit of proteins. The hydrogen bonds between amide linkages are the cause of existence of secondary structure of proteins. Low molecular amides, such as dimethylformamide are common solvents. Synthetically obtained polyamides are widely used in the form of various resilient materials. Thus, the possibility of prediction and theoretical prognosis of the structure and properties of amides of various classes of hydrocarbons is important for technological and fundamental scientific applications. In present work, the possibility of creation of extrapolation schemes for the prognosis of thermodynamic properties of amides was explored.

\section{Methods}

The quantum-chemical computations of electronic structure of the row of amides were carried out using PM3 (Parametrized Model 3) [1], SCF (Hartree-Fock) and MP2 (Moller-Plesset second order perturbation theory) methods. For ab-initio computations cc-pvdz basis set was [2]. The molecular geometric configurations were optimized at PM3 level and later used for ab-initio computations. The least squares method was used in order to estimate the degree of correlation between various measurable quantities. The degree of correlation was estimated by computation of correlation coefficient. The linear formula was utilized $y=K^{*} x+b$. Six parameters were used for building (arguments, functions) pairs of properties: number of carbon atoms (1), PM3 energy (2), SCF energy (3), MP2 energy (4), PM3 enthalpy of formation (5), experimental enthalpy of formation (6).

\section{Results and discussion}

The correlation coefficients of obtained models are shown in Table 2. As can be seen, the values of coefficients are close to 1 , which implies the linear character of correlation and correctness of chosen model. In addition, the fact that the values of correlation coefficients are close to 1.0 implies that it is possible to carry out linear extrapolations for every pair of properties. For the purposes of illustration a number of graphical representations of dependencies are shown in figures. The dependence of experimental enthalpy of formation on the number of carbon atoms is shown in Figure 1. The dependence of experimental enthalpy of formation on the SCF total electronic energy 
is shown in Figure 2. On Figure $3 \mathrm{SCF}$ energy is plotted as a function of PM3 energy. The dependence of correlation energy on the number of carbon atoms is depicted in Figure 4. On Figure 5 the dependence of ionization potential on the number of carbon atoms is shown. The interrelationship between the logarithm of ionization potential and protonation energy is shown in Figure 6.

Table 1 - Properties of amides

\begin{tabular}{|l|l|l|l|l|l|l|l|}
\hline & $\begin{array}{l}\text { Literature } \\
\text { data for } \\
\text { enthalpies } \\
\text { of } \\
\text { formation } \\
\text { /3/. }\end{array}$ & $\begin{array}{l}\text { Total } \\
\text { energies } \\
\text { estimated at } \\
\text { PM3 level of } \\
\text { theory, } \\
\text { kcal/mol }\end{array}$ & $\begin{array}{l}\text { SCF } \\
\text { energy, } \\
\text { a.u. }\end{array}$ & $\begin{array}{l}\text { MP2 } \\
\text { energy, } \\
\text { a.u. }\end{array}$ & $\begin{array}{l}\text { Protonation } \\
\text { energy, } \\
\text { a.u. }\end{array}$ & $\begin{array}{l}\text { Partial } \\
\text { charge on } \\
\text { N-atom } \\
\text { (Mulliken } \\
\text { model) }\end{array}$ & $\begin{array}{l}\text { Ionization } \\
\text { potential }\end{array}$ \\
\hline $\mathrm{HCONH}_{2}$ & -186.2 & -22.8 & -168.94 & -169.43 & -0.3079 & -0.2524 & -0.4051 \\
\hline $\mathrm{CH}_{3} \mathrm{CONH}_{2}$ & -237.9 & -28.3 & -207.99 & -208.62 & -0.3212 & -0.2389 & -0.3994 \\
\hline $\mathrm{C}_{2} \mathrm{H}_{5} \mathrm{CONH}_{2}$ & -248.1 & -33.8 & -247.03 & -247.79 & -0.3243 & -0.2363 & -0.3979 \\
\hline $\mathrm{C}_{3} \mathrm{H}_{7} \mathrm{CONH}_{2}$ & -275.7 & -39.3 & -286.06 & -286.98 & -0.3259 & -0.2353 & -0.3976 \\
\hline $\mathrm{C}_{4} \mathrm{H}_{9} \mathrm{CONH}_{2}$ & -296.4 & -44.8 & -325.1 & -326.15 & -0.3269 & -0.2360 & -0.3971 \\
\hline
\end{tabular}

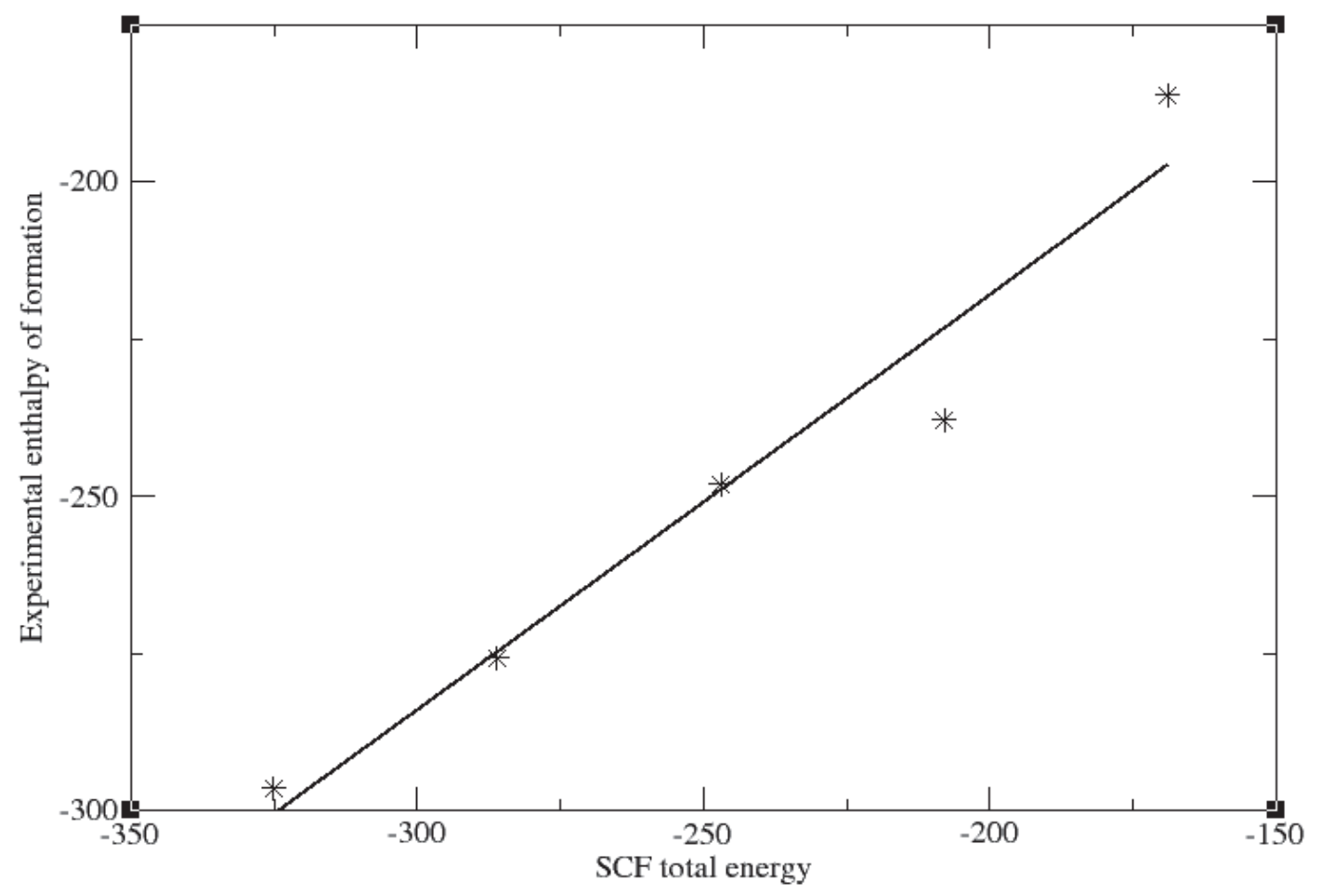

Figure 1: Experimental enthalpy of formation as a function of SCF total energy 


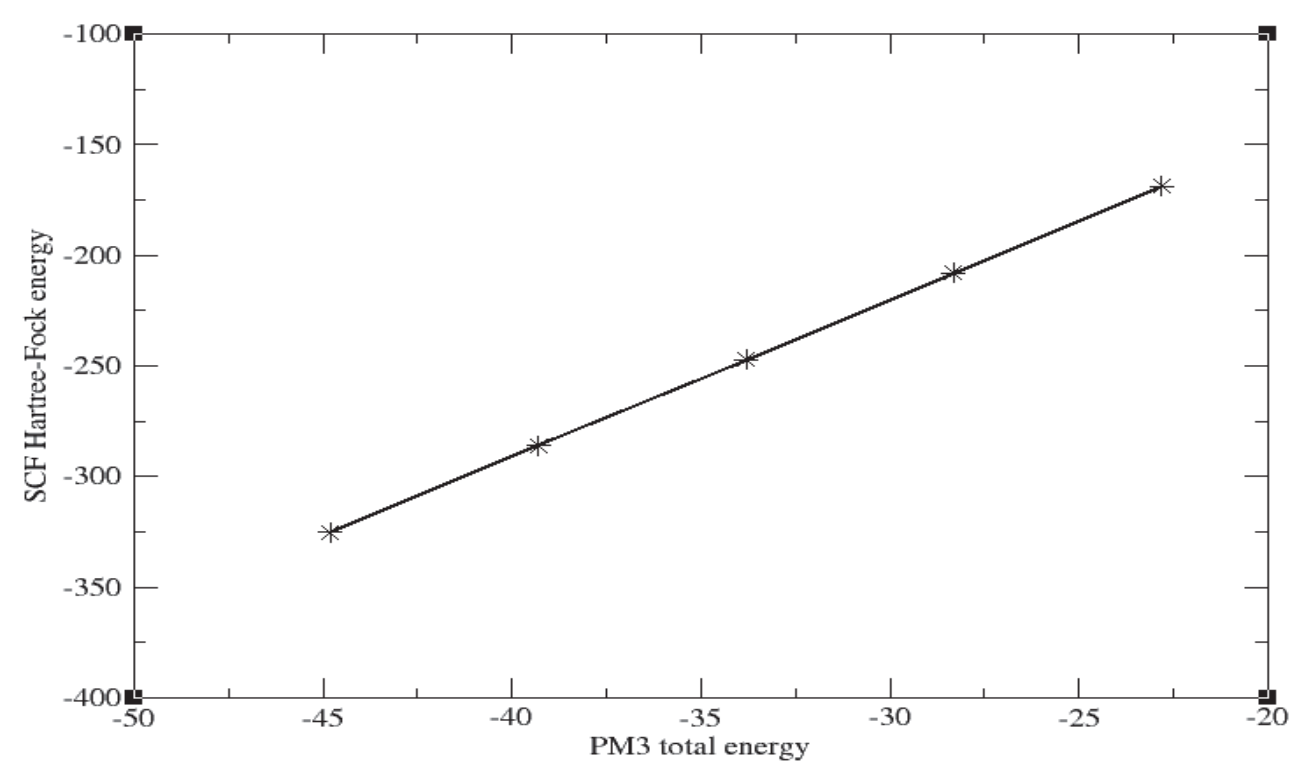

Figure 2: SCF Hartree-Fock energy as a function of PM3 total energy

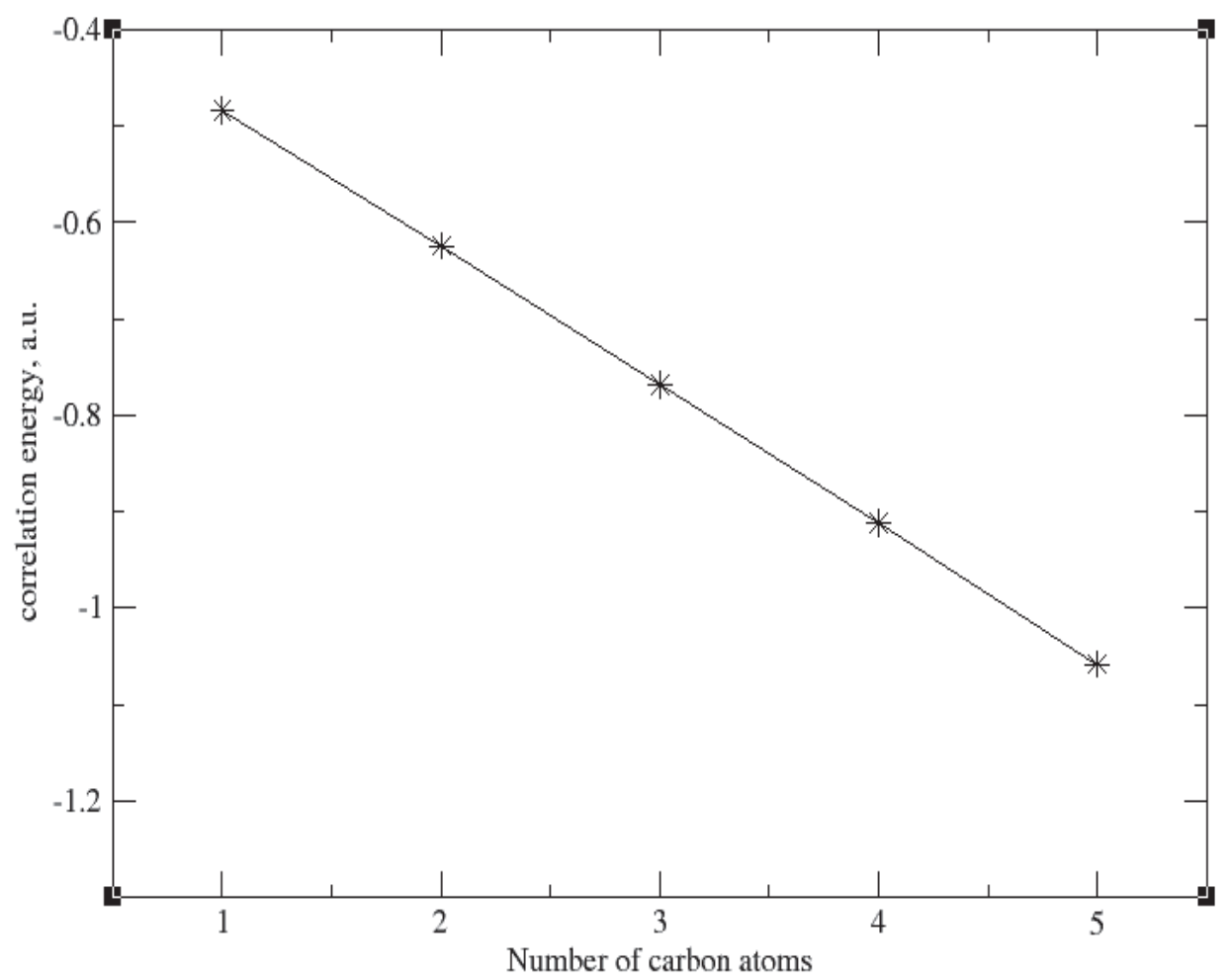

Figure 3: Correlation energy as a function of number of atoms 
Table 2: Correlation coefficients

\begin{tabular}{|l|l|l|l|l|l|l|}
\hline Property & 1 & 2 & 3 & 4 & 5 & 6 \\
\hline 1 & 1 & 1 & 0.99 & 1 & 1 & 0.97 \\
\hline 2 & 1 & 1 & 0.99 & 1 & 1 & 0.97 \\
\hline 3 & 0.99 & 0.99 & 1 & 0.99 & 0.99 & 0.99 \\
\hline 4 & 1 & 1 & 0.99 & 1 & 1 & 0.97 \\
\hline 5 & 1 & 1 & 0.99 & 1 & 1 & 0.97 \\
\hline 6 & 0.97 & 0.97 & 0.99 & 0.97 & 0.97 & 1 \\
\hline
\end{tabular}

Table 3: Linear coefficients $(K, b)$ of the $y=K * x+b$ models

\begin{tabular}{|c|c|c|c|c|c|c|c|}
\hline Property & 1 & 2 & 3 & 4 & 5 & & 6 \\
\hline 1 & $\begin{array}{l}(1.000, \\
0.000)\end{array}$ & $\begin{array}{l}(-5.496 \\
17.322)\end{array}$ & $\begin{array}{l}(-5.619 \\
-36.438)\end{array}$ & $\begin{array}{l}(-39.038 \\
129.910)\end{array}$ & $\begin{array}{l}(-39.182 \\
130.248)\end{array}$ & & $\begin{array}{l}(-25.822 \\
171.392)\end{array}$ \\
\hline 2 & $\begin{array}{l}(-0.182, \\
3.152)\end{array}$ & $\begin{array}{l}(1.000 \\
0.000)\end{array}$ & $\begin{array}{l}(1.022 \\
18.727)\end{array}$ & $\begin{array}{l}(7.103 \\
6.870)\end{array}$ & $\begin{array}{l}(7.129 \\
6.755)\end{array}$ & & $\begin{array}{l}(4.699, \\
89.998)\end{array}$ \\
\hline 3 & $\begin{array}{l}(-0.175, \\
6.304)\end{array}$ & $\begin{array}{l}(0.959 \\
17.324)\end{array}$ & $\begin{array}{l}(1.000, \\
0.000)\end{array}$ & $\begin{array}{l}(6.815 \\
116.179)\end{array}$ & $\begin{array}{l}(6.840, \\
116.745)\end{array}$ & & $\begin{array}{l}(4.644, \\
1.350)\end{array}$ \\
\hline 4 & $\begin{array}{l}(-0.026, \\
3.328)\end{array}$ & $\begin{array}{l}(0.141 \\
0.967)\end{array}$ & $\begin{array}{l}(0.144, \\
17.739)\end{array}$ & $\begin{array}{l}(1.000 \\
0.000)\end{array}$ & $\begin{array}{l}(1.004, \\
0.140)\end{array}$ & & $\begin{array}{l}\text { (0.661, } \\
85.459)\end{array}$ \\
\hline 5 & $\begin{array}{l}(-0.026, \\
3.324)\end{array}$ & $\begin{array}{l}(0.140 \\
0.947)\end{array}$ & $\begin{array}{l}\text { (0.143, } \\
17.759)\end{array}$ & $\begin{array}{l}(0.996 \\
0.140)\end{array}$ & $-\left(\begin{array}{l}(1.000 \\
0.000)\end{array}\right.$ & & $\begin{array}{l}(0.659 \\
85.552)\end{array}$ \\
\hline 6 & $\begin{array}{l}(-0.037, \\
6.143)\end{array}$ & $\begin{array}{l}(0.202 \\
16.439)\end{array}$ & $\begin{array}{l}(0.213, \\
0.369)\end{array}$ & $\begin{array}{l}-(1.434 \\
109.889)\end{array}$ & $\begin{array}{l}(1.439 \\
110.432)\end{array}$ & & $\begin{array}{l}(1.000) \\
0.000)\end{array}$ \\
\hline
\end{tabular}

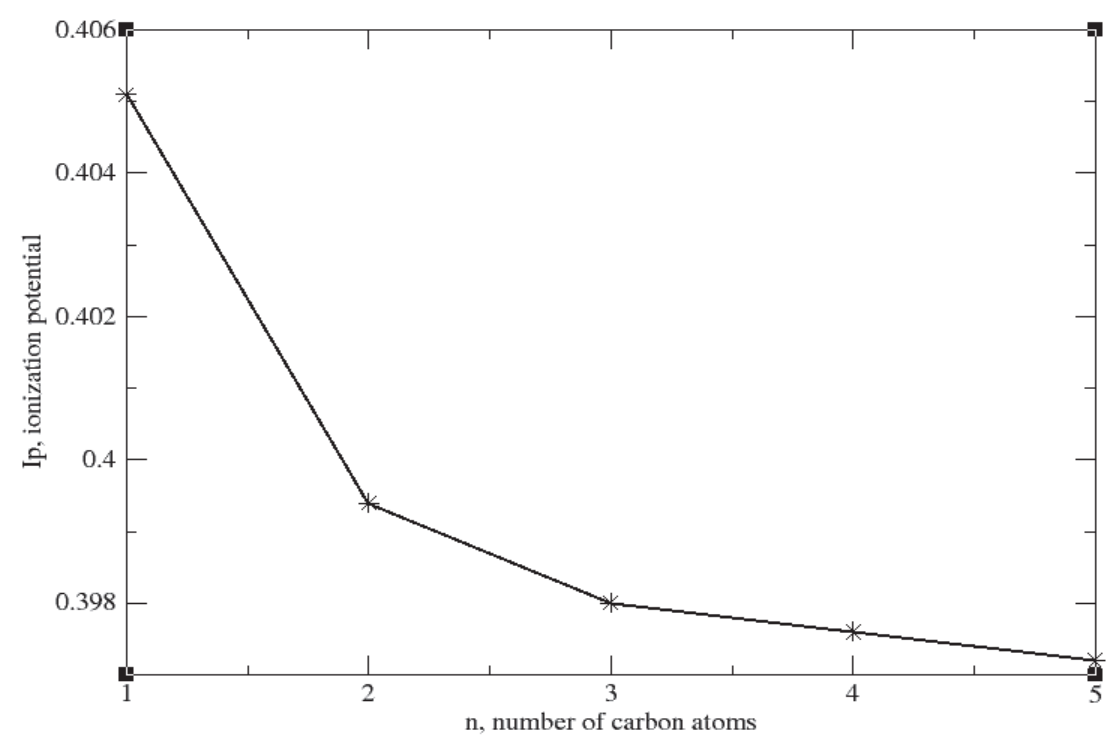

Figure 4: Ionization potential as a function of the number of carbon atoms 


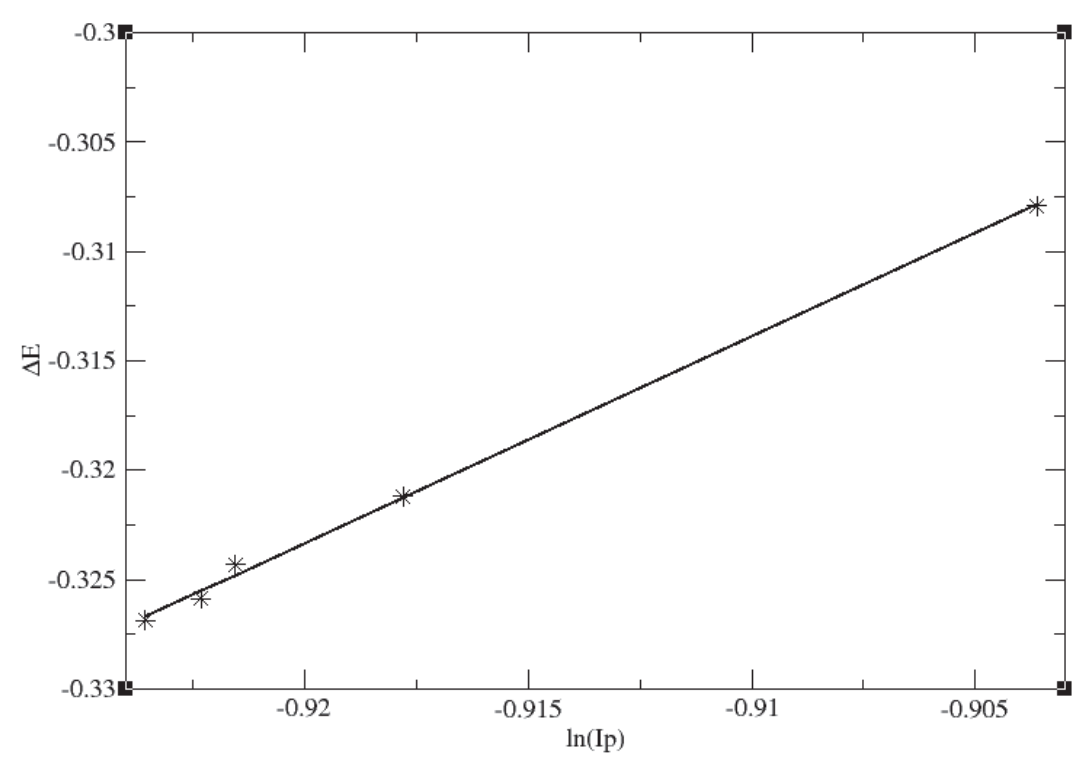

Figure 5: Protonation energy as a function of the logarithm of ionization potential. $\mathrm{E}_{\text {prot }}=0.54557+0.94446 * \ln \left(\mathrm{I}_{\mathrm{p}}\right)$. Correlation coefficient 0.999

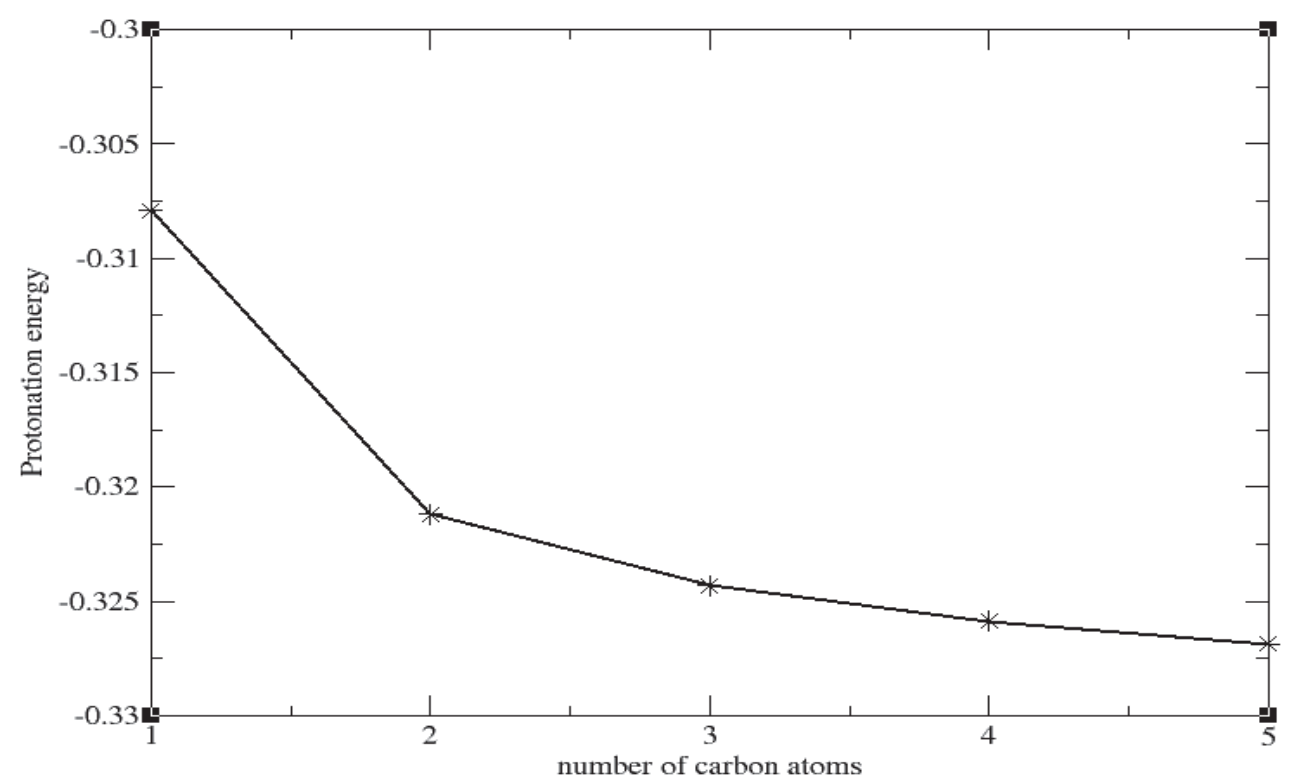

Figure 6: Protonation energy as a function of number of carbon atoms. Protonation energy in a.u.

Analysis of Figure 5 shows that lowering of absolute value of ionization potential leads to the increase of protonation energy, which can serve as an indirect illustration of the dominance of second order intramolecular polarization and charge-transfer effects in determining protonation energy. Protonation energy as a function of the number of atoms is plotted in Figure 6. Protonation energy may be used as an indicator of adsorption properties, as it characterizes the energy of interaction between the molecule and proton, and proton may be considered as a simplest field point resembling a molecule. Hence, as can be seen from the graphs, the degree of sorption properties of amides increases with the increase of the number of carbon atoms. The mechanism of such increase may be explained by considering partial charges on $\mathrm{N}$-atoms of free amides and ionization potentials of amide molecule. The general trend observed for partial charges shown in Table 1, estimated using Mulliken model, is that charges on N-atom decrease with the increase of the number of atoms. Such change may suggest that the first-order intermolecular electrostatic effects 
are not dominant in contributing to the increase of protonation energy. The second-order intramolecular polarization and charge transfer may be dominant, which is in agreement with the trend of decrease of ionization potential with the increase of the number of carbon atoms shown in Figure 5. It must be noted that ionization potential is inversely proportional to polarizability and polarizability determines the absolute values of second-order intermolecular polarization energies $[3,4]$.

The analysis of Table 2 reveals the possibility of construction of the wide range of correlation models. Of primary interest for this work is the linear correlation between total electronic energies of molecules and experimental enthalpies of formation of amides. Such linearity may allow the prognosis of properties of unknown compounds based on the result of ab initio computations. Another interesting dependence is between PM3 and SCF energies. This relationship opens new possibilities for "intermethod" extrapolations, where the exact SCF energy is hard to find due to complexity of the molecular system. The third important correlation observed is the linear relationship between the electron correlation energy and the number of atoms and the linear relationship between the electron correlation energy and SCF total electronic energy for the homologous series of amides. Such linearity opens new possibilities for "intermethod" extrapolations in the series of homologues. The fourth interesting correlation is the linear relationship observed between the natural logarithm of the ionization potential and the protonation energy. This correlation indicates the importance of intramolecular charge transfer effects in determining the degree of protonation energy, and, hence, the strength of adsorption, which can not be explained solely in terms of partial charges on interacting $\mathrm{N}$-atoms.

\section{Conclusion}

Several linear correlations were identified. Experimental enthalpies are in linear relationship with the number of carbon atoms in the alkyl chain. A linear correlation is observed between PM3 and SCF energies for the series of amides. The MP2 correlation energies are in linear dependence with the number of carbon atoms and with the SCF energies. Such correlations open new possibilities for extrapolations of enthalpies and total energies of arbitrary molecules belonging to a particular class of substance.

\section{References}

1. Stewart J.J.P. (1989). "Optimization of parameters for semiempirical methods I. Method // Journal of Computational Chemistry. - 1989. - V. 10. - N. 2. - p. 209

2. Dunning T.H.Jr. Gaussian-basis sets for use in correlated molecular calculations .I. The atoms boron through neon and hydrogen // Journal of Chemical Physics. - 1989 - V. 90. - N. 2. - P. 100

3. Abramova G.V. Computation and prognosis of thermochemical properties of organic amides. Dissertation for the degree of Doctor of chemical sciences, Almaty, 2007. 248 p.

4. Tulegenov A.S. SIMPER-P method for van der Waals complexes. PhD Thesis, Nottingham, 2006.

\section{КОРРЕЛЯЦИОННЫЕ МОДЕЛИ В ИССЛЕДОВАНИИ СТРУКТУРЫ И СВОЙСТВ АМИДОВ}

А.С.Тулегенов, Г.В.Абрамова, К.Акчурин, М.К.Наурызбаев, К.И.Иманбеков

В работе с использованием квантово-химических методов был исследован ряд амидов производных алканов. Были исследованы амиды ряда $\mathrm{C}_{1}-\mathrm{C}_{5}$. Полные электронные энергии были оценены на уровне методов ССП, МП2 и ПМЗ. Энтальпии образования были оценены на уровне метода ПМЗ. Была изучена возможность существования нескольких типов корреляций. Были рассчитаны следующие молекулярные свойства: потенциал ионизации, заряды на атомах азота, энергии протонирования. Было определено несколько линейных корреляционных соотношений: линейная взаимосвязь между экспериментальными энтальпиями и количеством атомов углерода, экспериментальными энтальпиями и полными электронными энергиями ССП, энергиями ССП и МП2 энергиями, логарифмом потенциала ионизации и энергиями протонирования для серии амидов. 


\section{АМИДТЕРДІҢ ҚУРЫЛЫМЫ ЖӘНЕ ҚАСИЕТТЕРІН ЗЕРТТЕУЛЕРДЕ ҚОЛДАНЫЛАТЫН КОРРЕЛЯЦИЯЛЫК МОДЕЛЬДЕР}

А.С.Төлегенов, Г.В.Абрамова, К.Акчурин, М.К.Наурызбаев, Қ.И.Иманбеков

Жұмыста кванттық-химия әдістерін қолдана отырып алкан туындыларының амидтер қатары зерттелінген. $\mathrm{C}_{1}-\mathrm{C}_{5}$ амидтер қатары зерттелінді. Толық электрондық энергиялары ССП, МП2 және ПМ3 әдістері деңгейінде бағаланды. Түзілу энтальпиялары ПМЗ әдісі деңгейінде бағаланды. Корреляциялардың бірнеше түрлерінің болу мүмкіндігі қарастырылды. Келесі молекулалық қасиеттері есептелінді: иондану потенциалдар, азот атомдағы зарядтар, протонизация энергиялар. Бірнеше сызықты корреляциялық байланыстары анықталған: экспериментальді энтальпиялар - көміртек атомдарының саны - толық электрондық энергиялары, иондану потенциалдың логарифмы - протонизация энергиялары. 